\title{
PENGETAHUAN DAN SIKAP TENTANG PORNOGRAFI PADA SISWA SMA SELAMA COVID-19
}

\author{
Hosea Perdhana Siahaan*, Nilawati Soputri \\ Fakultas Ilmu Keperawatan, Universitas Advent Indonesia, Jl. Kolonel Masturi No.288, Cihanjuang \\ Rahayu, Kec. Parongpong, Kabupaten Bandung Barat, Jawa Barat 40559, Indonesia \\ *dhanasiahaan@gmail.com (+6285279333301)
}

\begin{abstract}
ABSTRAK
Model dari penelitian ini adalah desktiptif dengan populasi sample kelas 1 dan 2 SMA dengan total 169 siswa. Pengambilan sampel ditetapkan berdasarkan siswa yang bersedia mengisi form kuesioner yang dibagikan dan diambil secara total sampling yaitu berjumlah 73 siswa, penelitian ini bertujuan untuk mengetahui tingkat pengetahuan dan sikap pada siswa sma dalam menanggapi pornografi selama covid-19. hasil yang didapatkan dari pengetahuan siswa adalah, $14 \%$ tinggi, $48 \%$ cukup, $36 \%$ remdah, dan $2 \%$ sangat rendah, dan hasil yang didapatkan dari hasil siswa adalah $62 \%$ baik dan $38 \%$ cukup baik, kesimpulan dari penelitian ini adalah bahwa siswa SMA Imanuel Bandar Lampung memiliki pengetahuan dan sikap yang baik dalam menanggapi pornografi.
\end{abstract}

Kata kunci: pengetahuan; pornografi; sikap; siswa

\section{KNOWLEDGE AND ATTITUDE TO PORNOGRAPHY IN HIGH SCHOOL STUDENTS DURING COVID-19}

\begin{abstract}
The model of this research is descriptive with a sample population of grade 1 and 2 SMA with a total of 169 students. Sampling was determined based on students who were willing to fill out the questionnaire form which was distributed and taken in total sampling, which amounted to 73 students, this study aims to determine the level of knowledge and attitudes of high school students in responding to pornography during covid-19. The results obtained from student knowledge are, $14 \%$ high, $48 \%$ moderate, $36 \%$ low, and $2 \%$ very low, and the results obtained from student results are $62 \%$ good and $38 \%$ quite good, the conclusion of this study is that students SMA Imanuel Bandar Lampung has good knowledge and attitude in responding to pornography.
\end{abstract}

Keywords: knowledge; pornography; attitude; students

\section{PENDAHULUAN}

Remaja adalah kelompok penduduk yang berusia 10-20 tahun. Masa ini merupakan masa peralihan dari masa kanak-kanak menuju dewasa yang produktif dan dapat bersosial dalam masyarakat (Santrock, 2007). Pada periode ini, individu mencari jati diri, berusaha untuk menunjukan eksistensinya, memiliki rasa ingin tahu dan penasaran yang tinggi, dan berani mengambil resiko. Pertumbuhan dan perkembangan remaja dibagi menjadi 3 tahap yaitu, remaja awal (11-14 tahun), remaja pertengahan (14-17 tahun), dan remaja akhir (17-20 tahun). Remaja pada tahap awal, belum memiliki pemahaman yang jelas tentang perubahan-perubahan yang terjadi pada diri mereka. Remaja pada tahap menengah, bergumul dari perasaan tergantung pada orang tua menjadi 
pribadi yang dapat untuk mandiri, dan remaja tahap akhir, telah memahami diri dengan baik dan memahami informasi abstrak yang sampaikan kepada mereka.

Pada masa remaja terjadi berbagai perubahan-perubahan biologis termasuk hormone-hormon seksual mulai aktif dan berfungsi pada tubuh manusia yang berpengaruh terhadap perilaku seksual, seperti merasakan cinta, ketertarikan kepada lawan jenis dan memiliki dorongan birahi (Hurlock, 1990). Tayangan media masa dan semakin mudahnya mengakses informasi secari digital termasuk pornografi akan sangat mempengaruhi pertumbuhan dan perkembangan remaja. Remaja yang menonton blue film, atau gambargambar pronografi, akan memberikan rangsang seksual yang dapat mempengaruhi perilaku seksual pada kelompok ini (Kartono, 2003)

Hadirnya poronogafi secara luas tidak telepas dari peranan internet dalam keseharian masyarakat terutama kaum remaja, di Indonesia banyak sekali ditemui masalah pada remaja, mulai dari pergaulan yang salah, kekerasan seksual dan pengunaan situs pornografi yang beredar luas. Dikarenakan kurangnya pengetahuan dan sikap dalam sebelelum memutuskan.Remaja sekarang dikenal sebagai generasi $\mathrm{Z}$ kelahiran tahun 1995-2010, yaitu generasi yang telah mengenal internet dari kecil. Generasi $\mathrm{Z}$ menggunakan internet, bukan hanya untuk pekerjaan dan penggunaan akademis, tetapi juga sebagai rekreasi (Kurnia santi et al. , 2019). Menurut penelitian yang didapat dari Universiti Kebangsaan Malaysia pada tahun 2016 yang dilakukan kepada 750 remaja, yang mendapati hasil terkaji generasi $\mathrm{Z}$ menggunakan internet 11,6 jam, data ini belum ditambah dengan penggunaan internet dengan tujuan lain seperti pemenuhan akademis, dari hasil penelitian yang dilakukan didapatkan bahwa ada 8 aplikasi yang sering digunakan yaitu facebook, whatsap, telegram, wechat, twitter, blog, youtube, dan instagram dan aplikasi yang sering digunakan adalah facebook (1,8 jam), instagram (1,8 jam), wechat (2,6 jam), dan yang paling lama adalah whatsap (4,2 jam). dan belum ditambah kan dengan penggunaan game online. ada 7 tingkatan dalam kecanduan internet, Pada tingkatan ini para remaja memliki tingkatan yang disebut dengan tingkatan kecanduan internet Compulsive symptoms (gejala kompulsif), dimana penggunaan internet menjadi aktivitas yang paling penting bagi hidup, mendominasi pikiran pengguna, kehidupan pengguna, perasaaan dan tingkah laku pengguna (Fatmalisa, 2014) selanjutnya pengguna yang mengalami kecanduan biasanya hanya akan terpuaskan dengan memikirkan aktivitas online (Chou, Condron \& Belland, 2005).

Pada saat ini dunia sedang menghadapi pandemi COVID-19. Infeksi Severe acute respiratory syndrome coronavirus 2 (SARS-CoV-2), yang secara klinis bermanifestasi terutama pada sistem pernapasan ini (COVID-19), memiliki tingkat penularan yang cukup tinggi di berbagai berbagai negara sehingga WHO akhirnya menetapkan status pandemi untuk penyakit infeksi tersebut.Hal tersebut bahkan telah mendorong beberapa negara untuk menerapkan kebijakan lockdown dalam rangka mencegah penyebaran virus ini secara luas dan masif (Kementerian Kesehatan Republik Indonesia, 2020).

Di Indonesia sendiri pada awal januari 2021, telah terdapat 368.842 kasus terkena covid-19 yang setiap harinya 
beratambah 3000 kasus. Pada masanpandemic Covid-19, pemerintah Indonesia telah menetapkan sebuah kebijakan implementasi dalam bentuk pembatasan jarak dalam arti membatasi akvitas fisik dan konntak diuluar rumah (Ahmed, Zviedrite and Uzicanin, 2018). Kebijakan tersebut menghimbau agar masyarakat melakukan proses berkerja, belajar dan beribadah di dalam rumah. Kebijakan tersebut, mengharuskan peserta didik, termasuk remaja, melakukan aktifitas belajar secara daring tanpa harus melakukan kontak fisik di sekolah (kementrian republik Indonesia, 2020). Bantuan kuota internet, diberikan oleh pemerintah RI kepada setiap siswa dalam memfasilitasi proses pembelajaran dan meringankan beban orang tua dalam membeli kuota. Namun, pemberian kuota internet secara cuma-cuma, dapat menyebabkan remaja menggunakan internet sepanjang hari, dan penggunaan internet menjadi lebih lama.

Proses pembelajaran dengan menggunakan internet seperti ini membuat remaja, akan terkena dampak akibat penggunaaan internet yang terlalu lama bagi penggunanya, baik itu dampak positive atau negative (Nugraha, 2013) jika tidak digunakan dengan bijak, hal tersebut akan memposisikan remaja untuk menggunakan internet sepanjang hari tanpa mengetahui apa yang menjadi prioritas pertama dalam hidup mereka. Dikarenakan penggunaan gadget sangat penting dalam membantu proses pemenuhan akdemik remaja, salah satu permasalahan di Indonesia pada remaja adalah tingginnya penggunaan situs pornografi pada saat pandemi covid-19. akibat penggunaan internet tidak pada tempatnya, denagn intensitas adiksi pornografi ini, memiliki resiko berprilaku seksual tidak sehat lima kali lebih besar dibandingkan dengan remaja yang berfrekuensi jarang (supriati dan fikawati, 2009). Adapun bentuk-bentuk prilaku seksual yang diakibatkan dari adiksi pornografi adalah mastrubasi (onani), dan berhubungan seksual (Karolina, 2002). Pada survey Standart Diagnosis Keperawatan Indonesia (SDKI)tahun 2017, didapati 50\% remaja pria dan $30 \%$ telah melakukan hubungan seks pranikah.

Banyak factor remaja mengakses situs pornografi, Salah satunya adalah Survey yang dilakukan, oleh pengembang akses situs pornografi di America serta hasil dari coordinator ECPAT(End Child Prostitution, Child Pornography And Trafficking of Children for Sexual Purposes) pada tanhun 2017 menyatakan, Indonesia berada dalam peringkat 2 dalam penggunaan situs dan konten pornografi. APJI menyebutkan bahwa pengguna internet paling banyak adalah usia 19-34 tahun(49,52\%), dengan jumlah penetrasi pemgguna akses internet paling banyak adalah 1318 tahun(75,5\%). Hal ini menunjukan banyak factor dalam siswa menggunakan situs pornografi. Ada juga hasil survei pada salah satu SMA di Bogor mengenai akses pornografi pada anak-anak yang dilakukan oleh Kementerian Kesehatan yang dipaparkan oleh Sekretaris Direktoral Jenderal Kesehatan Masyarakat Kemenkes menyebutkan dari 1.411 siswa pelajar SMP dan SMA kelas 1 dan 2 didapatkan hasil $97 \%$ dari responden pernah mengakses konten pornografi. Dengan ini dapat dikatakan, bahwa remaja tidak jarang menggunakan internet untuk mengakses pornografi.

Permasalahan dengan yang terkait dengan pornografi, peneliti akan melakukan survey dalam masalah ini. 
Adapun survey yang akan dilakukan adalah pemberian questioner mengenai pengetahuan dan sikap terhadap adiksi pornografi melalui situs web, dan media social lainya yang diberikan pada siswa sma imanuel Bandar lampung. diharapkan dari hasil observasi yang dilakukan peneliti akan dapat dilihat secara luas, tepat sasaran.

\section{METODE}

Penelitian ini di lakukan dengan menggunakan metode penelitian deskriptif. Populasi yang diambil dari penelitian ini berasal dari keseluruhan kelas 2 dan 3 sma Imanuel Bandar lampung, dengan total 169 siswa. Pengambilan sampel ditetapkan berdasarkan siswa yang bersedia mengisi form kuesioner yang dibagikan dan diambil secara total sampling yaitu berjumlah 73 siswa.

Pengumpulan data dilakukan dengan menggunakan kuesioner pengetahuan dan sikap terhadap pornografi. Penelitian dilakukan dengan memabagikan link questioner dengan bantuan aplikasi google form, yang akan diberikan ke grup whatsap atau media social lainya kepada anak murid kelas 2 dan 3sma Imanuel Bandar lampung. Analisis data menggunakan aplikasi microsof excel dengan spss versi 34 dan pengkategorian data untuk mengukur pengetahuan dibagi menjadi 4 kategori yaitu tinggi, cukup, rendah dan sangat rendah dan untuk sikap dibagi menjadi 2 kategori yaitu cukup baik dan baik.

\section{HASIL}

Pemaparan hasil penelitian terdiri dari karakteristik responden, tingkat pengetahuan tentang pornografi, dan sikap terhadap pornografi.

\section{Karakterristik Responden}

Kelompok umur yang mempunyai jumlah terbanyak sebagai responden adalah umur 16 tahun yaitu sebanyak 17 orang (44\%) dengan rata-rata umur responden yaitu 16. Kelas 11 mendominasi jumlah responden sebanyak 43 siswa (59\%). Sebanyak 44 (60\%)responden adalah sisiwi

\section{Tingkat pengetahuan tentang pornografi}

Tabel 1, menunjukkan mayoritas response memiliki pengetahuan yang cukup yaitu 35 responden (48\%).

\section{Sikap terhadap pornografi}

Table 2, dapat dilihat bahwa mayoritas responden memiliki sikap sikap yang cukup baik tentang pornografi yaitu 45 responden $(62 \%)$.

Table 1.

Tingkat Pengetahuan Siswa tentang Pornografi $(n=73)$

\begin{tabular}{lcc}
\hline \multicolumn{1}{c}{ Tingkat Pengetahuan } & $\mathrm{f}$ & $\%$ \\
\hline Tinggi & 10 & 14 \\
\hline Cukup & 35 & 48 \\
\hline Rendah & 26 & 36 \\
\hline Sangat rendah & 2 & 2 \\
\hline
\end{tabular}

Table 2.

Gambaran Sikap tentang Pornografi $(n=73)$

\begin{tabular}{lccc}
\hline & Sikap & f & $\%$ \\
\hline Cukup baik & 28 & 38 \\
\hline Baik & 45 & 62 \\
\hline
\end{tabular}


PEMBAHASAN

\section{Tingkat Pengetahuan tentang Pornografi}

Notoadmojo dalam Luthfianing dan Rosmita, 2017) menjelaskan bahwa pengetahuan adalah hasil yang terjadi setelah seorang individu melakukan pengindraan terhadap suatu hal atau objek tertentu. Pengindraan terhadap objek terjadi melalaui ke lima indra yang dimiliki manusia, yaitu pendengaran, penglihatan, penciuman, perasa, dan peraba. Sebagian besar pengetahuan manusia didapatkan melalui indra penglihatan dan pendengaran.

Pada penelitian ini pengetahuan siswa tentang pornografi mayoritas didapatkan dari internet $(65 \%)$ dan teman (13\%), ini sejalan dengan penelitian terdahulu oleh Rohani dan Febrianti (2014) menyatakan bahwa internet lebih banyak memberikan informasi dan pengetahuan kepada siswa dibandingkan media lain.

Menurut penelitian yang dilakukan oleh Zidna Sabela Naja, Farid Agushybana, Atik Mawarni (2017), pengetahuan atau teori kognitif merupakan bidang yang sangat penting dalam membentuk perilaku manusia (obvious behavior). Seseorang melakukan tindakan karena pengetahuan dan sikap yang dimilikinya. Hal ini dikarenakan internet sudah menjadi sumber informasi yang sangat mudah dijangkau terlebih di era pandemi covid-19 ini mengharuskan siswa untuk melakukan kegiatan belajar secara daring sehingga siswa mengharuskan siswa memiliki akses terhadap internet. Berdasarkan survei yang dilakukan KPAI ( komisi perlindungan anak Indonesia) dalam situasi pandemic covid-19, terdapat $22 \%$ anak indonesia yang masih melihat konten bermuatan pornografi.
Hasil penelitian tentang tingkat pengetahuan pornografi pada siswa di SMA Imanuel Bandar Lampung, mayoritas dalam kategori cukup yaitu 35 responden $(48 \%)$. Kognitif atau pengetahuan adalah hal yang sangat penting untuk membentuk prilaku seseorang. Menurut (Wawan dan Dewi, 2010) dengan memiliki pengetahuan yang baik akan membentuk sikap yang baik pula.

Gambaran Sikap tentang Pornografi Sumaryo 2013 (dalam I Dewa Made Ruspawan dan I Putu Dewi Citra Adnyana 2014)sikap terhadap beberapa objek dapat dianggap sebagai sikap visual atau emosional, tetapi sikap ini disertai dengan kecenderungan untuk bertindak sesuai dengan objek tersebut. menurut penelitian Feriyani dan Ahyani (2010), sikap adalah keyakinan termasuk suka atau tidak suka, penerimaan atau penolakan, positif atau negative untuk objek sikap.Sikap adalah fondasi individu menanggapi sesuatu. Sikap pribadi akan tercermin dalam bentuk perilaku yang diperlihatkan individu terhadap objek sikapnya.

Pada penelitian ini hasil hitung rata-rata nilai sikap terhadap pornografi menunjukan bahwa responden memiliki sikap yang cukup baik.Sebanyak $48 \%$ responden menjawab sangat setuju mengetahui pornografi sangat penting bagi kehidupan remaja.Donald (2004) menjelaskan pornografi dapat memberikan dampak prilaku negative namun dapat dilakukan upaya-upaya untuk mencegah atau mengurangi terjadinnya dampak negative akibat pornografi. Tentu dibutuhkan peran orang tua untuk mengawasi anak untuk lebih memperhatikan semua yang dilakukan, Djujur dan yayu (2020) menjelaskan bahwa saat komunikasi efektif terjalin antara orang tua dan anak 
maka akan memudahkan orang tua dalam hal pengawasan.

\section{SIMPULAN}

Siswa/siswi SMA Imanuel memiliki pengetahuan yang cukup dalam menanggapi pornografi dan memiliki sikap yang baik pula dalam menanggapi pornografi

\section{DAFTAR PUSTAKA}

Ahmed, F., Zviedrite, N., \& Uzicanin, A. (2018). Effectiveness of workplace social distancing measures in reducing influenza transmission: a systematic review. BMC public health, 18(1), 1-13.

Chou, C., Condron, L., \& Belland, J. C. (2005). A review of the research on Internet addiction. Educational psychology review, 17(4), 363388.

Dewi, A. P. (2015). Hubungan paparan pornografi melalui elektronik terhadap perilaku seksual remaja (Doctoral dissertation, Riau University).

Fatmalisa, S. (2014). Kecanduan Internet Pada Remaja dan Implikasinya Terhadap Layanan Bimbingan dan Konseling (Doctoral dissertation, Universitas Negeri Padang).

Feriyani, B., \& Fitri, A. R. (2011). Perilaku seksual pranikah ditinjau dari intensitas cinta dan sikap terhadap pornografi pada dewasa awal. Jurnal Psikologi, 7(2), 119152.

Hurlock, E. B., Istiwidayanti, Sijabat, R. M., \& Soedjarwo. (1990). Psikologi perkembangan: Suatu pendekatan sepanjang rentang kehidupan. Erlangga, Jakarta.

Isbaniah, F., Saputro, D. D., Sitompul, P. A., Manalu, R., \& Setyawaty, V. (2020). Pedoman Kesiapsiagaan Menghadapi Infeksi Novel Coronavirus (2019nCoV). Jakarta: Kementerian Kesehatan RI.

Kartono, K. (2003). Patologi sosial 3: Gangguan-gangguan kejiwaan. Jakarta: PT. Raja Grafindo Persada.

Kurniasanti, K. S., Assandi, P., Ismail, R. I., Nasrun, M. W. S., \& Wiguna, T. (2019). Internet addiction: a new addiction?. Medical Journal of Indonesia, 28(1), 82-91.

Kusmiran, E. (2011). Kesehatan reproduksi remaja dan wanita. Jakarta: Salemba Medika, 21.

Naja, Z. S., Agusyahbana, F., \& Mawarni, A. (2017). Hubungan pengetahuan, sikap mengenai seksualitas dan paparan media sosial dengan perilaku seksual pranikah pada remaja di beberapa SMA kota Semarang triwulan II tahun 2017. Jurnal Kesehatan Masyarakat (Undip), 5(4), 282293.

Supriati, E., \& Fikawati, S. (2009). Efek paparan pornografi pada remaja smp negeri kota pontianak tahun 2008. Makara Sosial Humaniora, 13(1), 48-56.

Wawan, A., \& Dewi, M. (2010). Teori dan pengukuran pengetahuan, sikap dan perilaku manusia. Yogyakarta: Nuha Medika, 12. 